\title{
MASIMO AS NONINVASIVE CONTINUOUS MONITORING FOR GUIDING FLUID IN INTENSIVE CARE UNIT
}

\author{
By \\ Ayman Saleh Mohammed Ragab \\ Department of Anesthesia and Intensive Care Department, Faculty of Medicine (Damietta), \\ Al-Azhar University \\ Corresponding author: Ayman Saleh Mohammed Ragab,
}

Mobile: (+20) 01019924895, E-mail: dr.aymansaleh72@yahoo.com

\begin{abstract}
Background: It is necessary to keep tracks of blood and fluid treatment during admission patient in intensive care unit Patient may have signs of hypovolemic but fluid administration is not always beneficial, we are in need of bedside devices and techniques which can predict fluid responsiveness effectively and safely.

The pleth variability indices (PVI) allow noninvasive assessment of fluid management.

It is based on respiratory changes in arterial pulse pressure. PVI reflect vascular tone, circulating blood volume and intra thoracic pressure.

Objective: To compare between PVI and CVP (central venous pressure) as effective measures to manage of fluid loading in monitorization in I.C.U.

Patients and Methods: This study was carried out at King Khaled Hospital between June 2017 and October 2018 on 200 randomized patients dividing into two equal groups: Group (I) measuring fluid by CVP, and Group (II) measuring fluid by Masimo to assess fluid management therapy.

Results: In comparison of fluid management in I.C.U, the amount of fluid replacement was $3500 \pm 1980.2$ in group (I), and $1913 \pm 540$ in group (II). There was no significant difference between the two groups in red blood cells transfusion or hemoglobin level.

Conclusion: Masimo can be used as bedside non-invasive technique to measure fluid responsiveness in operating room and intensive care unit without complication, and more reliable than some invasive technique in guiding fluid therapy.
\end{abstract}

Keywords: Surgery, Intensive Care Unit, fluid responsiveness, Central Venous Pressure, pleth variability index.

\section{INTRODUCTION}

No standard of fluid management intervention in I.C.U has yet been established (Van Regemortel et al., 2014). However, excessive fluid replacement harms all body functions, while the lifethreatening consequence of inadequate fluid support leads to tissue hypoxia, acidosis and organs failure (Cumpstey et al., 2016).

Prediction of fluid responsiveness had been challenge for many years. Fluid responsiveness known as the ability of the circulation to increase cardiac output (CO) in response to volume expansion (Feldman et al., 2012). 
Conventionally, parameters such as heart rate, blood pressure, urine output, central venous pressure (CVP) and blood loss are measured during admission in I.C.U to calculate necessary amount of fluid (Desai and Gari, 2018). Hemodynamic optimization by intravenous (IV) fluid administration is very important to correct any fluid deficits created by fasting and other critically ill patients to improve oxygen delivery and overall hemodynamic function (Guerin et al., 2013).

Method of volume response assessment can be classified to static measure like HR, MAP, and CVP (Liu et al., 2019).

Dynamic measure, e.g., pulse pressure variation (PPV) stroke volume variation (SVV) which is invasive maneuver has been used instead of static measure (Matta et al., 2019).

Invasive maneuver is not preferable as difficult measurement. So, the minimally invasive method like PV1 has been used increasingly for noninvasive assessment of fluid management (Monnet et al., 2016). It is based on respiratory changes in arterial pulse pressure (Piskin and $\ddot{O} z$, 2017).

Masimo machine uses 7 wave lengths of light to continuously and non-invasive measurement of arterial oxygen saturation (SPO2), pulse rate (PR) and perfusion index ranging from $0.02 \%$ to $20 \%$ along with optional measurement of hemoglobin (SPHB), carboxyl hemoglobin (SPCO), total oxygen content (SPOC), meth hemoglobin (SPMET), Oxygen reserve index (ORI) and pleth variability index (PVI) that reflect physiologic factors such as vascular tone circulating blood volume and intra-thoracic pressure it ranging from $0 \%$ to $100 \%$.

Masimo is valid for use in adult, pediatric patients in motion or no motion in law and high perfusion condition and in hospital and home. This machine had color coding acting as warning sign for anesthetics to check early changes intraoperative to prevent complication. Grey no monitoring. Green monitoring normal range. Yellow monitoring cautions range. Red monitoring alarm range. Also, this machine parameter gives idea about our body system, e.g. Cardio: pulse rate. Respiratory: SPO2, SPCO, Vascular: PI, PVI, SPHB, SPMET and Brain: PSI (Piskin and $\ddot{O} z, 2017$ ).

The PV1 is preferred because it is noninvasive, the sensor can be easily inserted, and it allows continuous measurement at the bedside (Piskin. et al., 2017). Monitoring fluid management in I.C.U is assessed by using PVI, CVP and classical hemodynamics signs (Wise et al., 2017).

The present work aimed to monitoring fluid management during major interventions, we aimed to compare fluid loading-induced changes as assessed using PVI, CVP and classical parameters.

\section{PATIENTS AND METHODS}

The present study was carried out on patient who admitted in I.C.U in King Khalid Hospital in Nagran city. K.S.A in between 2017/2018 on 200 patients after written informed consent was obtained from every patient, legal guardian after explaining the procedure and its potential complication. Patients were divided randomly by sealed envelope into two groups Group (I) measuring fluid by CVP 
Group (II) measure fluid by Masimo to assess fluid management therapy.

Inclusion criteria: Patient $\geq 21$ year old. , ASA status I, II. Patient admitted to I.C.U. Patient needs of I.V fluid challenge for Resuscitation based on clinically character mainly hypo perfusion state symptoms \& sign.

Exclusion criteria: No written consent Patient under 21 years. Cardiac and peripheral arterial disease. Contraindication to fluid resuscitation e.g. congestive heart failure renal failure.

The collected data include patient demographics American society of anesthesiology (A.S.A) classification hemodynamics monitoring (measured continuously the following values blood pressure, heart rate at statistical analysis base all patient were evaluated in I.C.U at $0,5,10,30,60$ and 120 minutes specifically heart rate, Mean arterial pressure (MAP) peripheral oxygen saturation and CVP were measured, Hemoglobin (HB) and hematocrit levels were recorded at the beginning, middle and end of 1 st day.

In the group (II) total HB level and PVI values were also recorded at 5 minutes intervals. The data were compared between both groups to assess fluid management.

Primary outcome: to assess fluid by measuring perfusion index which ranging from $0.02 \%$ to $20 \%$ and PVI which ranging from $0 \%$ to $100 \%$ above $15 \%$ means good volume assess and no needed to increase fluid therapy in group ( II ). In group ( I ) we measure central venous pressure when above $5 \mathrm{~mm}$ hg which good indicator of fluid supply.
Secondary outcome: include MAP, HB\%, HCT\% and urine output in both group.

In the I.C.U we used standard monitoring method, E.C. G, noninvasive BLP. SPO2 and end tidal $\mathrm{CO} 2$.

\section{We divided our patients into two equal} groups: Group ( I ) which was controlled group though CVP has inserted, and group (II) where we used PVI machine. All patients were fully assessed with general physical examination and demographic data and (APACHE) II score.

In I.C.U, we used standard methods electrocardiogram, non-invasive blood pressure, peripheral oxygen saturation end tidal $\mathrm{CO} 2$ pressure (ETCO2).

In group ( II ), a PVI, probe (Radical$7^{\circledR}$; Masimo Crop., Irvine, CA, USA) was placed on the patient's index finger and protected from light. No invasive arterial monitoring was carried out. A peripheral oxygen saturation probe was placed on the index finger of the other hand. In patients with a PVI greater than $14 \%, 250 \mathrm{~mL}$ of crystalloid solution was administered all over 5 minutes, whereas a fluid infusion was delivered at a dose $4 \mathrm{ml} . \mathrm{Kg}$ - $\mathrm{h} 1$ to patients with a PVI $<14 \%$. Blood loss was calculated and the blood loss was replaced.

\section{Statistical analysis of data:}

Data were expressed as mean values \pm standard deviation, percentage [\%] and numbers $[\mathrm{N}]$. A statistical Package performed the statistical analysis for Social Science [SPSS] version20 [IMB ${ }^{\circledR}$ SPSS $^{\circledR}$ Inc., Chicago, IIlinois, USA]. Two statistical tests were primarily used to analyze the difference between numerical data, and $\mathrm{p}$ value $<0.05$ was considered 
statistically significant. T-test was used to analyze differences between the two groups; analysis of variance [ANOVA] was used to analyze differences in more than two means. However, Chi-square test was used to compare categorical data.

\section{RESULTS}

Both groups were comparable as regard to demographic data (age, height, weight, BMI and comorbidities ) as regard age $(57.30 \pm 12.50)$ to $(54.68 \pm 13.61)$ APACHE $(24.50 \pm 5.02)$ to $(25.50 \pm 4.50)$
BMI, mean $\pm \mathrm{SD}, \mathrm{kg} / \mathrm{m} 2(28.00 \pm 2.69)$ to $(27.60 \pm 3.59) \quad$ No significant and difference between two groups except in HT and CAD (Table 1).

\section{Table (1): Patient demographics}

\begin{tabular}{|c|c|c|c|}
\hline $\begin{array}{ll}\text { Patient demographics } & \text { Groups } \\
\end{array}$ & $\begin{array}{c}\text { Group ( I ) } \\
(\mathbf{n}=\mathbf{1 0 0})\end{array}$ & $\begin{array}{c}\text { Group (II) } \\
(\mathbf{n}=100)\end{array}$ & $\mathbf{p}$ \\
\hline Age, mean \pm SD, years & $57.30 \pm 1450$ & $55.68 \pm 14.61$ & $>0.005$ \\
\hline Height, mean $\pm \mathrm{SD}, \mathrm{cm}$ & $169.02 \pm 9.30$ & $167.43 \pm 9.29$ & $>0.005$ \\
\hline Weight, mean $\pm \mathrm{SD}, \mathrm{kg}$ & $81.40 \pm 8.24$ & $80.13 \pm 9.89$ & $>0.005$ \\
\hline BMI, mean $\pm \mathrm{SD}, \mathrm{kg} / \mathrm{m}^{2}$ & $28.00 \pm 2.69$ & $27.60 \pm 3.59$ & $>0.005$ \\
\hline Body surface area mean $\pm \mathrm{SD}, \mathrm{m}^{2}$ & $1.93 \pm 0.13$ & $1.92 \pm 0.15$ & $>0.005$ \\
\hline APACHE II & $24.71 \pm 6.02$ & $26.23 \pm 4.60$ & $>0.005$ \\
\hline \multicolumn{4}{|l|}{ Comorbidities } \\
\hline COPD & $1(1 \%)$ & $1(1 \%)$ & $>0.005$ \\
\hline $\mathrm{DM}$ & $13(13 \%)$ & $13(13 \%)$ & $>0.005$ \\
\hline HT & $19(19 \%)$ & $19(19 \%)$ & $>0.005$ \\
\hline CAD & $4(4 \%)$ & $4(4 \%)$ & $>0.005$ \\
\hline CVD & $0(0)$ & $0(0)$ & $>0.005$ \\
\hline
\end{tabular}

Data were expressed as mean \pm standard deviation frequency $(\mathrm{N})$ percentage $(\%)$

COPD: chronic obstructive pulmonary disease DM: diabetes mellitus HT: hypertension CAD: coronary artery disease CVD: cardiovascular disease.

In the comparison of fluid management in I.C.U the amount of fluid replacement was $(3500 \pm 1980.2)$ in group (I) and (1913 \pm 540 ) in group (II). The mean unit of red blood cell transfusion was $0.06 \pm 0.23$ in grope (I), $0.66 \pm 0.82$ in group (II), the mean total urine output was $475.20 \pm 278.29$ in group (I) and $521.00 \pm 309.88$ in group (II) (Table 2). 
MASIMO AS NONINVASIVE CONTINUOUS MONITORING FOR...

Table (2): Comparison of fluid management variables

\begin{tabular}{|l|c|c|c|}
\hline Fluid management $\quad$ Groups & $\begin{array}{c}\text { Group ( I ) } \\
(\mathbf{n = 1 0 0})\end{array}$ & $\begin{array}{c}\text { Group ( II ) } \\
(\mathbf{n = 1 0 0})\end{array}$ & P value \\
\hline I.C.U & & & \\
\hline Fluid management & & & \\
\hline Total fluid (mL) & $3522 \pm 1098.1$ & $1914 \pm 542.86$ & $<0.0001$ \\
\hline Given ES (pack) & $0.42 \pm 0.57$ & $0.08 \pm 0.27$ & $<0.001$ \\
\hline Given FFP (pack) & $0.06 \pm 0.23$ & $0.00 \pm 0.00$ & $>0.005$ \\
\hline Total urine output & $475.20 \pm 278.29$ & $521.00 \pm 309.88$ & $>0.005$ \\
\hline Bleeding amount & $286.00 \pm 88.08$ & $286.00 \pm 70.73$ & $>0.005$ \\
\hline Blood transfusion & $0.44 \pm 0.57$ & $0.66 \pm 0.82$ & $>0.125$ \\
\hline
\end{tabular}

Data were expressed as mean \pm standard deviations: estimated FFP: fresh frozen plasma

As comparable both groups, there were statistically significant decreases between two groups $\mathrm{Hb} 1 \mathrm{PC}(12.68 \pm 1.69)$ in group (I) $(12.65 \pm 1.57)$ in group (II). No significant were found between the groups in $\mathrm{Hb} 2 \mathrm{PC}$ $(-0.11(-0.23: 0.19)$ in group (I) $(-0.04(-$
0.23:0.02) in group (II). there were significant decrease in group (I) than Group (II) in terms of Htc $1 \mathrm{PC}(39.14 \pm 5.51)$ in group (I) (39.07 \pm 4.93$)$ in group (II). Also Htc 2 PC in both groups (Table 3).

Table (3): Comparison of hemoglobin and hematocrit percentage change

\begin{tabular}{|l|c|c|c|}
\hline Hemoglobin \%changes $\quad$ Groups & $\begin{array}{c}\text { Group ( I ) } \\
(\mathbf{n = 1 0 0 )}\end{array}$ & $\begin{array}{c}\text { Group ( II) } \\
(\mathbf{n = 1 0 0 )}\end{array}$ & P value \\
\hline Hb 0 & & & \\
\hline Hb 1 PC & $12.68 \pm 1.69$ & $12.65 \pm 1.57$ & $>0.005$ \\
\hline Hb 2 PC & $-0.11(-0.23: 0.19)$ & $-0.04(-0.23: 0.02)$ & $>0.003$ \\
\hline Htc 0 & $-0.12 \pm 0.09$ & $-0.09 \pm 0.06$ & $>0.005$ \\
\hline Htc 1 PC & $39.14 \pm 5.51$ & $39.07 \pm 4.93$ & $>0.005$ \\
\hline Htc 2 PC & $-0.10(-0.22: 0.13)$ & $-0.05(-0.19: 1.83)$ & $>0.002$ \\
\hline Hb PC & $-0.12(-0.28: 1.88)$ & $-0.09(-0.22: 0.11)$ & $>0.013$ \\
\hline Htc Pc & $-0.03(-0.30: 0.21)$ & $-0.06(-0.27: 0.30)$ & $>0.005$ \\
\hline & $-0.03(-0.30: 0.23)$ & $-0.07(-0.29: 2.13)$ & $>0.005$ \\
\hline
\end{tabular}

Hb: Hemoglobin Htc: Hematocrit, PVI: Pleth Variability index, PC Percentage changes.

Data were expressed as mean $\pm \mathrm{SD}$, median (min: $\max$ )

The change from baseline in HR, mean \pm $\mathrm{SD}$, beats/min $(93.81 \pm 8.59)$ in group (I) $(91.50 \pm 6.42)$ in group (II). No statically significant difference in the change of any HR in both groups from baseline. Significant difference were found between the two groups in term of MAP, mean $\pm \mathrm{SD}$, $\mathrm{mmHg} \quad(62.56 \pm 5.17)$ in group (I) $(69.30 \pm 5.20)$ in group (II) from baseline PVI, mean \pm SD $(\%)(17.85 \pm 2.58)$ in group (I) $(11.65 \pm 2.39)$ in group (II) with significant difference (Table 4). 
AYMAN S. RAGAB et al.,

Table (4): Comparison of Hemodynamic percentage value changes

\begin{tabular}{|c|c|c|}
\hline Hemodynamic difference & $\begin{array}{c}\text { Group ( I ) } \\
(\mathbf{n = 1 0 0 )}\end{array}$ & $\begin{array}{c}\text { Group ( II ) } \\
(\mathbf{n = 1 0 0})\end{array}$ \\
\hline HR, mean \pm SD, beats/min & $93.81 \pm 8.59$ & $91.50 \pm 6.42$ \\
\hline MAP, mean \pm SD, mmHg & $62.56 \pm 5.17$ & $69.30 \pm 5.20^{* *}$ \\
\hline CVP, mean \pm SD, mmHg & $4.20 \pm 2.27$ & $5.15 \pm 2.33^{* *}$ \\
\hline CI, mean \pm SD, $\mathrm{L} / \mathrm{min} / \mathrm{m}^{2}$ & $2.76 \pm 0.20$ & $3.20 \pm 0.20^{* *}$ \\
\hline PVI, mean \pm SD $(\%)$ & $17.85 \pm 2.58$ & $11.65 \pm 2.39^{* *}$ \\
\hline
\end{tabular}

Values were expressed as mean \pm SD Cl cardiac index, CVP central venous pressure, HR heart rate, PVI pleth variability index, frequency (N) percentage (\%) SD standard MAP: Mean Arterial blood Pressure.

The difference between CVP and PVI regarding performance at threshold value of CVP $\geq 5 \mathrm{MM} \mathrm{Hg}$ and PVI $\geq 14$, sensitivity at threshold value of $>14 \%$ provided $93 \%$ while CVP group sensitivity $79 \%$ and specificity of PVI was $87 \%$, while CVP was $47 \%$. So, there were significant differences between CVP and PVI in Sensitivity and Specificity (Table 5).

Table (5): Comparison of performance between parameters

\begin{tabular}{|c|c|c|}
\hline Performance & CVP & PVI \\
\hline Threshold value & $\geq 5 \mathrm{mmHg}$ & $>14 \%$ \\
\hline Sensitivity & $70.83 \%$ & $93.75 \%$ \\
\hline Specificity & $47.5 \%$ & $87.5 \%$ \\
\hline P-value & $>0.005$ & $<0.0001$ \\
\hline
\end{tabular}

CVP: Central Venous Pressure, PVI: pleth variability index

\section{DISCUSSION}

In our present prospective study, randomized clinical trial involved patients who had received fluid replacement under the guidance of either PVI or CVP monitoring in ICU (Stawicki. et al., 2015).

Mortality and morbidity can be reduced by proper fluid management in patients in I.C.U interventions. Noninvasive monitors, who can measure parameters continuously and in a dynamic manner, are becoming increasingly important. In patients in I.C.U, Fluid management is routinely monitored by measured static preload parameters (heart rate, MAP and CVP).

In a meta-analysis done by Liu. et al. (2019), they concluded that PVI has a good bedside reliability in ICU. Also, it has a limited ability in prediction of fluid responsiveness in general (Liu. et al.,
2019) However, Chu, et al. (2019) showed that PVI had higher sensitivity of fluid responsiveness in ICU. However, static parameters fail to track the patient's response to fluid loading (Bacchin et al., 2016).

So, PVI measurements have revealed the circulating blood volume more effective than CVP measurement that can be affected by bolus administrations.

PVI is preferable as it decreases mortality and morbidity incidence ( $\mathrm{Yu}$ et al., 2015). Studies have suggested that dynamic markers, such as PVI, SVV, and PPV, are more successful and reliable in evaluating response to fluid management. However, SVV and PPV are invasive measurement methods. Automatic and continuous PVI monitoring is noninvasive technique that measures the effects of changes in ventilation on the wavelength 
of the pulse oximetry (Morgam et al., 2014).

Forget. et al. (2010) reported that high volume fluid replacement in patient with the renal failure in intensive care unit negatively affected mortality and morbidity. In follow up study by Willner et al, (2016), they indicated that fluid replacement has similar consequence in high-risk patient.

In the present study, both groups showed significant difference in initial MAP between the groups. There was no significant difference in MAP during the follow up period (Morgam et al., 2014).

A guide for accurate blood transfusion strategies, liberal and restrictive form studies showed that restrictive fluid management has positive effect rather than liberal on early prognosis, length of hospital stay, wound healing, and pulmonary rehabilitation. The American society of anesthesia (ASA) reported that targeted fluid therapy decreases postoperative complications and length of hospital stay. In another study (Willner et al., 2016). Separated patients into two groups, implementing of liberal blood transfusion strategy in one group (intraoperative $\mathrm{Hb} \geq 10 \mathrm{mg} \mathrm{dl}-1$ ), and a restrictive transfusion strategy in the other group (intraoperative $\mathrm{Hb} 7-8 \mathrm{mg} \mathrm{dl}-1$ ). In addition, more blood transfusion was performed in the liberal group, whereas more fluid replacements were performed in the restrictive group. The need for postoperative transfusion was greater in the restrictive group than in the liberal group due to heart failure, hypotension, and tachycardia. In the present study, the amount of intraoperative red blood cell transfusion was significantly lower in the group ( II ). However, there was no difference in the amount of blood loss between the groups. In the present study, the frequency of transfusions was lower in the group ( II ) than in the literature. In the present study, intraoperative $\mathrm{Hb}$ levels were above $10 \mathrm{mg} \mathrm{dl}-1$ in both groups, and neither group saw and hemodynamic change during follow-up that may have caused $\mathrm{Hb}$ deterioration. PVI monitoring is thought to reflect the blood volume status more accurately than CVP monitoring, and it may be more useful in major surgeries, especially when volume changes occur that may affect the hemodynamic, PVI monitoring may also be a useful guide for accurate blood transfusion strategies.

Restrictive fluid therapy can ultimately lead to multiple organ failure or even death through hypervolemia and organ dysfunction, whereas exaggeration of liberal fluid management can lead to edema, resulting in reduced cardiac function, pulmonary edema, coagulation and bleeding disorders, and renal insufficiency. In a Meta -analysis by Jia et al. (2017) cardiopulmonary complications were more frequent in patients undergoing major abdominal surgery who under liberal fluid management.

The deleterious effect of over fluid transfusion on different organs made a continuous need for new dynamic indicators for fluid management which are more preferable than unreliable static ones (Sakr et al., 2017) That was obvious in our study as CVP was a weak predictor for fluid responsiveness with best threshold value $\geq 5 \mathrm{~mm} \mathrm{Hg}$ of 0.612 (0.502 to 0.714$)$. 
Dynamic methods in fluid responsiveness identification are more accurate (Guerin et al., 2013 and Theerawit et al., 2016), but some of them require invasive procedures like arterial line insertion, and also, not all of them can provide continues readings. Minimally or non-invasive cardiac output monitors have the least prerequisites and can be used in a variety of critically ill patients for estimating CO rapidly (Jalil and Cavallazzi, 2018).

\section{CONCLUSION}

The present study indicated that PVI can be used in assessment of fluid responsiveness in I.C.U better than CVP. It is advantage in non-invasive technique can be performed at the bedside with continuance monitoring and more reliable than other invasive method, and provided better cardiac stabilization with less fluid replacement and more accurate result in the evaluation of body intravascular volume status.

\section{REFERENCES}

1. Bacchin, M. R., Ceria, C. M., Giannone, S., Ghisi, D., Stagni, G., Greggi, T and Bonarelli, S. (2016): Goal-directed fluid therapy based on stroke volume variation in patients undergoing major spine surgery in the prone position: a cohort study. Spine, 41(18): E1131-E1137.

2. Cumpstey AF, Grocott MP and Mythen MMG (2016): Fluid management and its role in enhanced recovery, In Perioperative Fluid Management pp. Pbl.Springer, Cham., pp. 299-32.

3. Desai $\mathbf{N}$ and Gany D (2018): Assessing dynamic fluid-responsiveness using transthoracie echocardiography in intensive care. BIA Education, 18(7): 218-226.
4. Feldman JM, Sussman E, Singh D and Friedman BJ (2012): Is the pleth variability index a surrogate for pulse pressure variation in a pediatric population undergoing sping fusion, Paediatr Anaesth., 22:250-5.

5. Forget $P$, Lois $F$ and de Kock $M(2010)$ : Goal directed fluid management based on the pulse oximeter-derived pleth variability index reduces Lactate levels and improves fluid management. Anesth Analg., 111: 910-4.

6. Guerin $\mathbf{L}$, Monnet $X$ and Teboul JL (2013): Monitoring volume and fluid responsiveness: from static to dynamic indicators. Best Practice \& Research Clinical Anesthesiology, 27(2): 177-185.

7. Jalil BA and Cavallazzi $R$ (2018): Predicting fluid responsiveness: a review of literature and a guide for the clinician. The American Journal of Emergency Medicine, 36(11): 2093-2102.

8. Jia Fj, Yan QY ,Sun Q,Tuxun T, Liu H and Shao $L$ (2017): Liberal versus restrictive fluid management in metaanalysis. Surg today, 47:344-56.

9. Liu T, Xu C, Wang M, Niu Z and Qi D (2019): Reliability of pleth variability index in predicting preload responsiveness of mechanicall ventilated patient under various conditions: a systematic review and meta-analysis BMC. Anesthesiology, 19(1): 1-7.

10. Matta JL, Kraemer CE. Tuinman PR and van Westerloo DJ (2019): POCUS series the use of velocity time integral in assessing cardiac output and fluid responsivenss. Netherlands Journal of critical Care, 27(5): 196-198.

11. Monnet X, Marik PE and Teboul JL (2016): Prediction of fluid responsiveness. An update. Annals of Intensive Care, 6(1): 111. 
12. Morgam GE, Mikhail Ms and Murray MJ (2014): Larson CP. Fluid management and transfusion in: Clinical Anesthesiology, Fifth Ed Pbl. New York: The MacGraw-Hill Companies. , 154=3-8 pp.

13. Pişkin, Ö. and Öz, İ. İ. (2017): Accuracy of pleth variability index compared with inferior vena cava diameter to predict fluid responsiveness in mechanically ventilated patients. Medicine, 96(47) 192199.

14. Sakr Y, Rubatto Bim PN, Kotis k, Nanchal R. Shah B and Kluge $S$ (2017): Higher fluid balance increases the risk of death from sepsis results from a large international audit. Critical Care Medicine, 45(3): 386-394.

15. Stawicki, S. P., Kent, A., Patil, P., Jones, C., Stoltzfus, J. C., Vira, A., ... and Bahner, D. P. (2015): Dynamic behavior of venous collapsibility and central venous pressure during standardized crystalloid bolus: A prospective, observational, pilot study. International Journal of Critical Illness and Injury Science, 5(2): 80-85.
16. Theerawit P, Morasert Tand Sutherasan Y (2016): inferior vena cava diameter variation compared with plus pressure variation as predictors of fluid responsiveness in patients with sepsis Journal of Critical Care, 36:246-251.

17. Van Regenmortel N, Jorens PG and Malbrain ML (2014): Fluid management before, during and after elective surgery Curr Opin Crit Care, 20: 390-5.

18. Willner D, Spennati V, Stohl S, Tosti G and Aloisio Bilotta F (2016): Spine Surgery and Blood Loss: Systematic Review of Clinical Evidence. Anesth Analg. , 123:1307-15.

19. Wise R, Faurie M, Malbrain ML and Hodgson E (2017): Strategies for intravenous fluid resuscitation in trauma patients. World Journal of Surgery, 41(5): 1170-1183.

20. Yu Y, Dong J, Xu Z, Shen Hand Zheng (2015): J. Pleth variability index-directed fluid management in abdominal surgery under combined general and epidural anesthesia J. Clin Monit Comput, 29: 4752. 


\section{إستخدام جهاز ماسيهو كمراقبة مستمرة غير جراحية لتوجيه السوائل فى وحلدة العناية المركزة ميرة فيرة

$$
\text { أيمن صالح محمد رجب الفهاه }
$$

قسم التخدير والغناية المركزة بكلية الطب (دمياط) جامعة الازهر

E-mail: $\underline{\text { dr.aymansaleh72@yahoo.com }}$

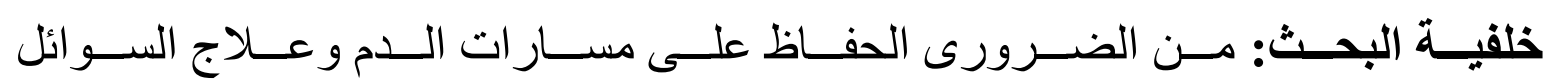

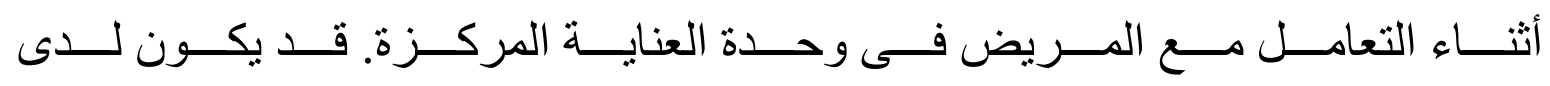

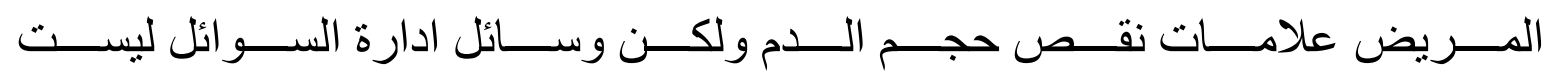

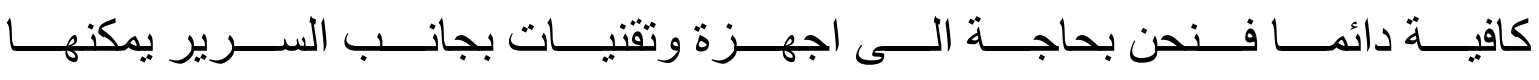

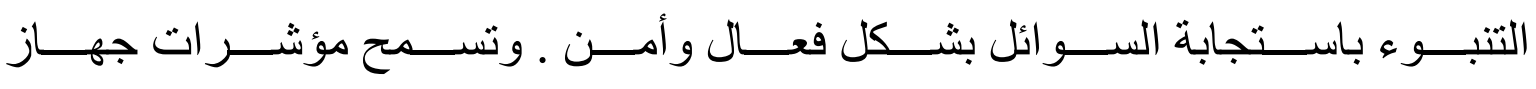

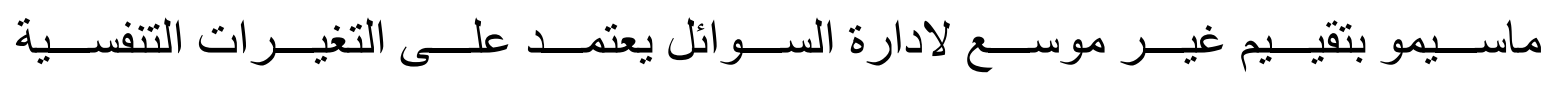

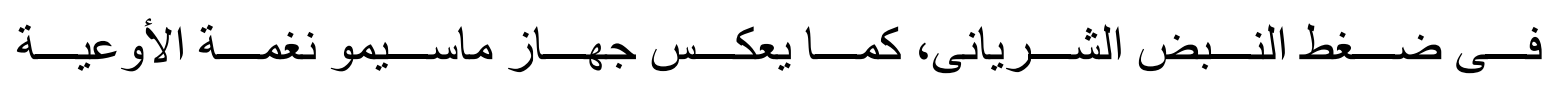
الادموية وحجم الدم المنتشر و الضغط داخل الصدر.

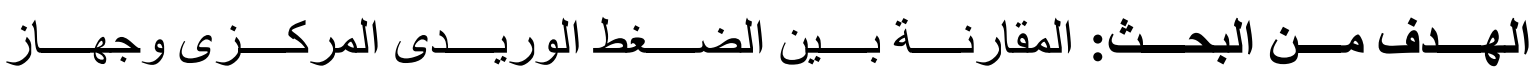

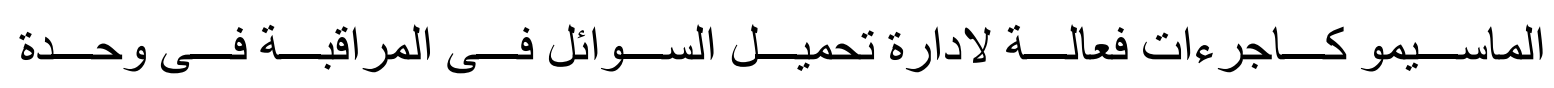

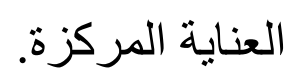

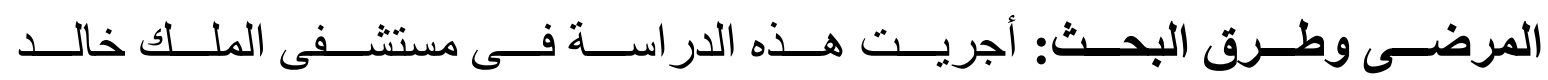

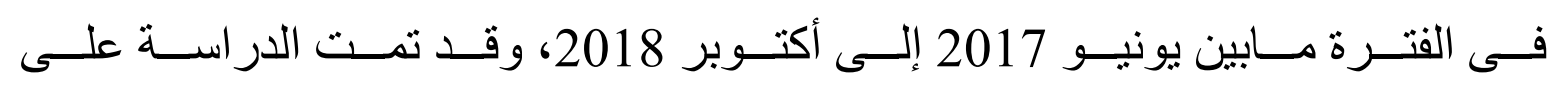

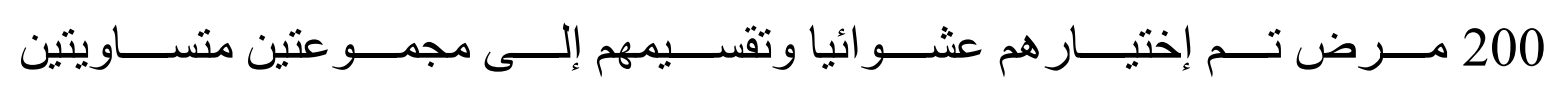

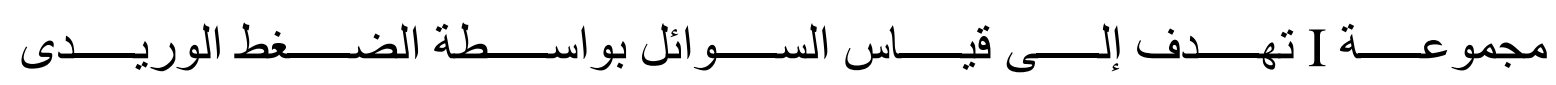

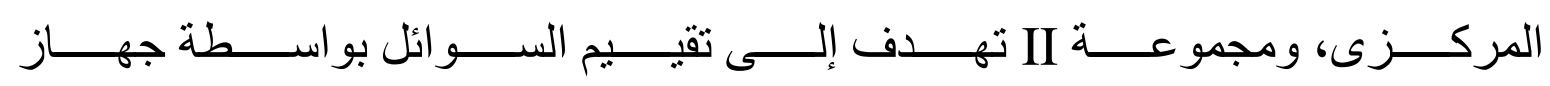
الماسيمو، وذلك على مريض العناية المركزة. 
تتــائج البحـــث: فــى مقارنــة إدارة الســـو ائل فــى وحــدة العنايـــة المركــزة كانـــ

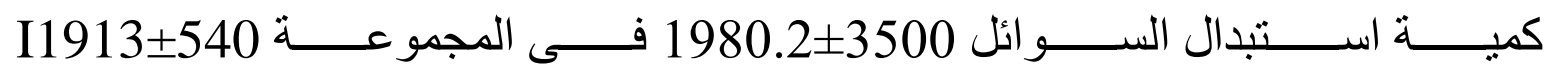
كـــا كانــت فــى المجمو عــة II وكــذلك لــوحظ عــدم وجــود فــرق كبيــر بــين المجمو عتين فى نقل خلايا الدم الحمر اء أو مستوى الهيموجلوبين.

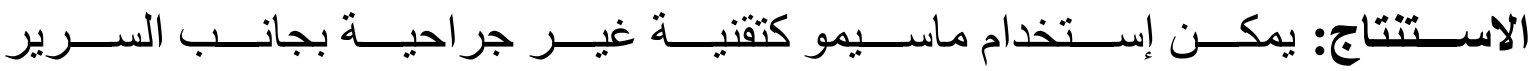

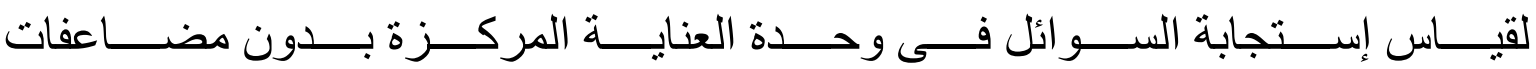

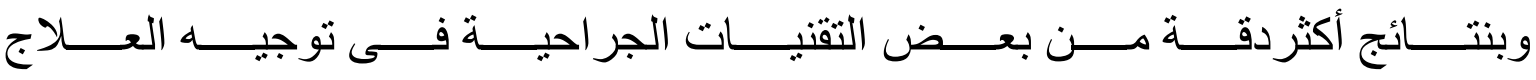

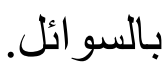

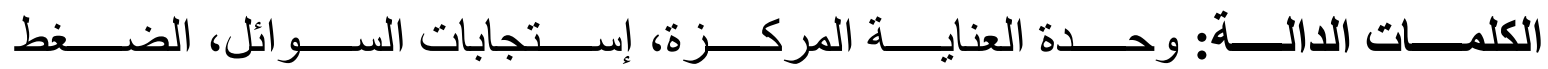
الوريدى المركزى، الجراحة، مؤشر تغيير بليث. 